\title{
OKINAVOS MITYBOS FENOMENO ANALIZE்: ATVEJO TYRIMAS
}

\author{
Irma Spiriajevienė \\ Klaipédos valstybinès kolegijos Sveikatos mokslu fakultetas
}

Raktažodžiai: Okinava, Japonija, mityba, atvejo tyrimas.

\section{Santrauka}

Tyrinejjamai temai analizuoti buvo naudojamas atvejo tyrimo būdas, pasitelkiant literatūros analizès metodą, kuris buvo tinkamiausias ištirti tolimos Rytų Azijos šalies Japonijos pietuose esančios Okinavos prefektūros gyventojų mitybos atveji. Atvejo tyrimas igalino pristatyti platų tyrinejjamos temos kontekstą, kuris straipsnyje atskleistas istoriniu, socialiniu (visos šalies bei Okinavos, išsidèsčiusios vienoje iš 161 Riukiu salyno salų) aspektais. Tyrimo kontekstas plètojamas analizuojant ir prevencinị požiūrị ị sveikatą, netinkamos mitybos pavojus bei kitas svarbias su tiriamuoju atveju susijusias aplinkybes.

Okinavos salos gyventojai taip pat, kaip ir visa šalis, atlaikę Antraji pasaulinį karą, ne tik pakilo ir apstulbino planetą neitikètina ekonomikos pažanga, perèjimu prie pasaulinès technologinès lyderystès, bet ir nustebino pasauli atradę jaunystès eliksyrą, kuri didžiąja dalimi lemia okinavietiška mityba. Okinavos salos moterų vidutinè gyvenimo trukmé (VGT) - 86 metai, vyrų - 78 metai, o per šimtą metų gyvenančių žmonių 100 tūkstančių salos gyventojų statistiškai tenka 34 žmonès (JAV - 7-8). Nustatyta, kad pasaulyje didžiausia ilgaamžių koncentracija yra būtent Japonijos Okinavos saloje ir tai vadinama fenomenaliu gerontologiniu reiškiniu. Be to, svarbu, kad šių gyventojų sveikata gana ilgą laiką išlieka stipri, o sergamumas širdies ir kraujagyslių, onkologinemis bei kitomis ligomis yra mažesnis nei kitose šalyse. Japonijos Okinavos salos gyventojų atvejo fenomenalumas ilgaamžiškumo kontekste slypi vietinių gyventojų mitybos tradicijoje, kurios analizè išryškino šiuos Okinavos salos gyventojų mitybos raštingumo postulatus: neriebus maistas, augalinès kilmès produktų (ypač daržovių, jūros dumblių) vartojimas, visadalių grūdų, flavonoidų, omega-3 riebiụjų rūgščių, kurių nemažai yra žuvyje, vartojimas, uogų, vaisių (ypač karčiojo žaliojo meliono) vartojimas bei gau- sus ciberžolès, žaliosios bei jazminų arbatos gèrimas. Dauguma okinavų, kurių saloje gyvena 1,3 mln., yra apriboję mèsos, saldumynų, kavos vartojimą. Išryškèjo ir tai, kad ramus Okinavos salos gyventojų charakteris, pasitenkinimas gyvenimu, nuolatinè veikla, fizinis judejjimas, darnus santykis su kitais bei maisto ruošimo ir valgymo filosofija - tai mitybos veiksni papildantys ištekliai, taip pat turintys reikšmès gerai šios salos gyventojų sveikatai ir pasaulyje garsėjančiam okinaviškajam ilgaamžiškumui.

\section{Ivadas}

Apsiribojimo filosofija yra kenksminga kiekvienai nacionalinei bendruomenei, atriboja ją nuo pasaulio, prie kurio nesiliesdama bendruomené patenka ị stagnaciją. Integracija i pasaulio gyvenimą leidžia suvokti savo paties primityvumą ir skatina perimti tai, kas vertinga, nes tik taip tauta gali išsilaikyti. Svarbu neapsiribojant siaura lietuviškaja ar europietiškaja terpe ieškoti moksliškai pagrịstų pozityvių sveikatos proveržių atvejų.

Nauja epocha mus skatina keisti mąstyseną ir požiūrị i sveikatą. Sveikatos srityje yra atliekama vis daugiau mokslinių tyrimų. Labai dažnai šių tyrimų sudedamoji dalis yra Rytų medicinos ir gyvensenos studijos. Atsakymų i sveikos gyvensenos, ilgaamžiškumo ir sveikos mitybos klausimus verta paieškoti Rytų Azijos kultūros tradicijose. Viena iš mokslo patikrintų ir vis daugiau visuomenès dèmesio sulaukianti yra japoniška mityba, didžiąa dalimi nulèmusi japonų, ypač Okinavos salos gyventojų, ilgaamžiškumą, sveikatą bei gyvenimo kokybę. Okinava užima pirmą vietą pasaulyje pagal vidutinę gyvenimo trukmę (VGT), kuri siekia 81,2 metus (likusioji Japonijos dalis - 79,9 metus).

Tyrimo tikslas - paanalizuoti Japonijos Okinavos salos gyventojų mitybos atvejị kaip fenomenalų reiškinį, duodantị nuorodą i jų gerą sveikatą ir ilgaamžiškumą.

\section{Tyrimo metodika}

Naudojamas literatūros analizès metodas, taikant atvejo (case study) tyrimo būdą. Informacija apie atvejị, kaip teigiama mokslo tiriamojo darbo metodologų, gali būti ren- 
kama įvairiais būdais bei metodais ir to pasirinkimas nèra pagrindinè tyrimo kokybės išraiška - svarbiausia yra atsakyti i tyrimo klausimą. Tyrimo atvejis - yra unikalus, specifinis, neịprastas, nereprezentuojantis platesnès visumos objektas. Esminis atvejo tyrimo kriterijus - atvejo išskirtinumas (angl. boundedness). Šiame darbe pasirinktas objektas, pasižymintis išskirtinai gerais rezultatais. Tai okinavietiškoji mitybos tradicija.

Atvejo studijos taikytinos tik kai tyrejjas gali aiškiai nusakyti atvejo ribas. Tiriamasis atvejis gali būti konkreti žmonių grupé, gyvenanti tam tikroje konkrečioje teritorijoje. Šiame darbe atvejo ribos turi aiškią apibrežtị - tai Japonijos pietuose Ramiojo vandenyno Riukiu salyne esanti Okinavos sala, kurioje gyvena $1,3 \mathrm{mln}$. gyventojų. Taikoma viena iš atvejo analizès rūšių - vidinè atvejo studija - kai tiriamas atvejis, norint suprasti jo ypatingumą (7). Pagrindinis atvejo tyrimo privalumas - gilinimasis ị žmonių elgsenos ir veiklos ypatumus, tyrimui reikšmingus objekto požymius, jo prigimtį, raidą, istorinį kontekstą, fizinę aplinką, vidinius ir išorinius ryšius, psichologinius ir kitus aspektus, sąsajas su kitais objektais ir pan., kuriuos sudètinga apčiuopti kitomis socialinio tyrimo strategijomis. Dèl to reikia paanalizuoti tiriamojo atvejo kontekstą, nes tokiais tyrimais siekiama aprèpti plačiai, holistiniu požiūriu. Taigi, siekiant atskleisti Azijos rytuose esančios Okinavos salos sveikos mitybos ypatumus, verta paanalizuoti Japonijos istorinę bei socialinio vystymosi raidą, sveikatos prevencijos ypatumus, netinkamos mitybos pavojus, japoniškosios kultūros bei mitybos filosofijos subtilumus bei kitas svarbias su tiriamuoju atveju susijusias aplinkybes.

\section{Rezultatai ir jų aptarimas}

Okinavos prefektūros socialinis kontekstas Japonijos istoriniu aspektu. Ekonomikos pletros, technologinès transformacijos ir socialinès raidos procesas, kurị pusę šimto metų vykdè Japonija, pakilusi iš savo sutriuškintų imperialistinių ambicijų pelenų, pasauliniame kontekste yra laikomas fenomenaliu reiškiniu (3). Japonijos istorija pakeitè pasaulị ir mūsų supratimą apie jo raidą. Japonijos gamtinès aplinkos kraštovaizdis keitėsi, tačiau šalies kultūrinis tapatumas buvo išsaugotas ir tapo puikiu modernizavimo (bet ne vakarietinimo) istoriniu pavyzdžiu. Be abejo, Japonijos visuomenè turèjo daug daugiau dirbti, negu Amerikos ir Europos gyventojai, vartoti gerokai mažiau ir ilgą laiką kur kas daugiau taupyti bei investuoti. Buvusi nuskurdinta šalis, visiškai priklausoma nuo kitų valstybių tiekiamų elektros energijos bei gamtinių išteklių, sutelkè jègas: iš pradžių, kad išgyventų, po to, kad galètų konkuruoti, ir galiausiai, kad įsitvirtintų pasitelkusi pramonès gamybą, ekonomikos valdymą bei technologinę naujadarą (3). Taigi, Japonijos ekonomikos plètros strategijoje laipsniškai pereita nuo pasivijimo prie pasaulinès technologinès lyderystès (5).

Japonija yra viena iš labiausiai kultūriškai bei socialiai homogeniškų pasaulio visuomenių, nors ir ịskaitant milijonus imigravusių korejjiečių, nemažai ainų bei okinavų gyventojų (3). Šiek tiek labiau išsiskirianti iš homogeniškosios Japonijos visuomenès savo dialektu, kultūra ir tam tikrais požiūriais ị gyvenimą yra Okinavos prefektūra, išsidèsčiusi vienoje iš 161 Riukiu salyno salų Ramiajame vandenyne Pietų Kinijos jūroje. Okinavos saloje nuo XV a. vid. apie $400 \mathrm{~m}$. viešpatavo Riukiu karalyste, o vietovè vadinosi Manzamo - „vieta, skirta visiems suteikti gero". Tai jaučia ir šiandieniniai vietiniai gyventojai bei svečiai. Didžiausiame Okinavos salos mieste Nahoje (prefektūros admin. centras, 320000 gyv.) yra jūrų ir oro uostai, saloje labai gerai išplètota infrastruktūra, viešbučiai, poilsiavietès. Okinavos gyventojai taip pat, kaip ir visa šalis, atlaikẻ Antraji pasaulinį karą, tačiau ne tik pakilo ir apstulbino planetą neįtikètina ekonomikos pažanga, perèjimu prie pasaulinès technologinès lyderystès perèjimu prie pasaulinès technologinès lyderystès, negana to, nustebino pasaulị atradę jaunystès eliksyrą, kurị didžiaja dalimi lemia okinavų mityba. Okinavos moterų VGT - 86 metai, vyrų - 78 metai, o per šimtą metų gyvenančių žmonių 100-ui tūkstančių gyventojų yra 34 žmonès (JAV - 7-8) (8).

Senas populiarus okinaviečių posakis, kad ,laimė ateina iš jūros" duoda nuorodą ị žuvininkystę ir pagaunamas žuvis bei kitas jūros gèrybes. Šalies geografinè padètis iš dalies nulemė japonų mitybos pasirinkimą. Auginti gyvulius yra sunku, nes žemès bei ganyklų yra nedaug, tad karvių ir kitų gyvulių auginama mažai. Prioritetas tenka žuvininkystei. Japoniškosios technologijos, pvz., specializuoti žvejybos laivai aprūpinti ịranga, leidžia ne tik gaudyti, bet ir apdoroti, konservuoti bei išsiųsti žuvị tos pačios kelionès metu (5). Subtropinio klimato Okinavoje auginami ryžiai, cukranendrès, batatai, ananasai, daržovės ir kt.

Prevencinio požiūrio ị sveikatą prieiga. Pasaulio sveikatos organizacijos pateiktame sveikatos apibrèžime nurodoma, kad sveikata yra visiškos fizinès, psichikos ir socialinès gerovès būsena, o ne vien ligos ar negalès nebuvimas. Tai išryškina pozityvaus individo funkcionavimo aspektą ir orientavimąsi ị ligų prevenciją. Sveikatos problemų tyrinèjimas dar ne taip seniai buvo grindžiamas vien patogeniniu požiūriu ir vyravo medicininè sveikatos problemų prieiga ị sveikatos problemas. Tačiau apsiribojus dėmesio sutelkimu i sergančiuosius, buvo nepelnytai ,pamiršti“ sveikieji, jų gyvensena, psichosocialiniai, aplinkos, kultūros bei mitybos veiksniai, kas didžiaja dalimi lemia žmogaus sveikatą.

Sveikata turi būti stiprinama ne tuomet kai žmogus suserga (kaip ir plaukti mokomès ne tuomet, kai skęstame). Prisiminus medicinos kūrimosi laikus, slypi įdomus faktas, 
kad medicina atsirado pirmiausia kaip prevencija, orientuota ị sveikatos stiprinimą ir palaikymą. Tik daug véliau buvo pereita prie ligų ir medicina tapo orientuota ị gydymą. Senovès Kinijoje buvo priimta, kad gyventojai savo gydytojams atlyginimą moka tol, kol yra sveiki, bet kai suserga, nebemoka. Ligų prevencijai Rytų Azijos šalyse ir dabar skiriama nemažai dėmesio, kai Vakarų šalys ligų prevenciją ir mitybos faktorių vis dar ignoruoja, pirmenybę teikdamos kovai su ligomis. Tačiau sveikatos tyrimų duomenys rodo, kad pasaulio Vakarų šalių gyventojų sveikata ir gyvenimo trukmé nepaprastai skiriasi nuo Japonijos gyventojų - Jungtinès Valstijos pagal vidutinę gyvenimo trukmę užima 24 vietą (vieną iš paskutiniujjų tarp išsivysčiusių pasaulio šalių), priešingai nei Japonija - pirmą pasaulyje (8).

Moksliniais tyrimais jau seniai įrodytas ryšys tarp mitybos ir sveikatos. Pasaulio sveikatos organizacijos (PSO) bei įvairių mokslinių tyrimų duomenimis, netinkama mityba neigiamai veikia gyventojų lètinių neinfekcinių ligų (kraujotakos sistemos ligos, piktybiniai navikai, cukrinis diabetas ir kt.) vystymąsi bei didina gyventojų mirtingumą. Dèl netinkamų maitinimosi ịpročių didèja antsvorio ir nutukimo problemos, sparčiai plinta kavos gèrimas, ịtraukiantis priklausomybėn vis jaunèjančią visuomenès dalị. Lietuvoje beveik kas antras gyventojas turi antsvorio ar yra nutukęs (1). Netinkamos studentų mitybos tendenciją rodo tyrimas, kuriuo nustatyta, kad tik apie 80 proc. studentų (Lietuvoje ir kitose pasaulio šalyse) KMI yra normalus (4). Neatsakingos elgsenos pasekmés pasireiškia ne iš karto ir visuomené nelinkusi prognozuoti netinkamos mitybos padarinių, kurie yra susiję su negalavimais bei ligomis, o kartais ir mirtimi.

Japonijoje, o ypač Okinavos saloje, širdies ir kraujagyslių ligos pasitaiko labai retai ir yra labai lengvos formos, kitos ligos taip pat yra retesnès nei kitų šalių gyventojų (1 lentelè).

Tausojant sveikatą ir ją atkuriant, gana svarbūs vadinamieji „laimès hormonai“ - geros, teigiamos mintys, pozityvus nusiteikimas, šypsena skatina šių hormonų gamybą, o tai veikia ne tik mentalinę sriti, bet yra glaudžiai susiję ir su fizinèmis funkcijomis - veikla, energingumu (2). Taip stiprinama imuninè sistema yra prevencija ligoms. Laimè ir sveikata yra neatskiriamos - anot Ajurvedos, jei esi sveikas, bet nesi laimingas, vadinasi, nesi sveikas.

Analizuojant Okinavos salos gyventojų prevencinị sveikatos aspektą, galima teigti, kad didžiausią ịtaką jų sveikatai daro ne genetika, o mityba bei prie to prisidedantis fizinis aktyvumas ir socialiniai ryšiai. Ivvertinant ramų okinavų charakterị, pasitenkinimą gyvenimu, nuolatinę veiklą, fizinị judejimą, darnų santykị su kitais, galima teigti, kad tai taip pat svarbūs postulatai, turintys reikšmès stipriai šios salos gyventojų sveikatai.

Okinavos salos gyventojų valgymo kultūra ir mitybos tradicijos. Japonijos visuomenės orientavimasis ị grupę bei nuo seno įaugęs homogeniškumas akivaizdus ir valgymo bei maisto ruošimo kultūroje. Dažnai valgoma sėdint prie bendro stalo, kurio viduryje verda šeimos patiekalas. Ramus nusiteikimas, pagarba vienas kitam, estetika užima svarbią vietą okinavų valgymo kultūroje.

Okinavų mityba, kaip ir likusios Japonijos dalies gyventojų mityba, laikoma sveikiausia pasaulyje $(2,8)$. Dèl to yra svarbu paanalizuoti vietiniu gyventojų mitybos tradicijas, maisto racioną, apdorojimą, patiekalus. Moksliniais okinaviškosios mitybos patirtimi grịstais bei kitais naujais tyrimais yra ịrodyta, kad daug angliavandenių ir mažai kalorijų turintis maistas, kuriame vyrauja augalinès kilmès produktai, yra pats naudingiausias žmogaus sveikatai, nes tai mažina širdies ligų, vėžio, insulto riziką bei normalizuoja KMI (8). Okinavos gyventojai iš angliavandenių gauna 54 proc. kalorijų (8).

Pats populiariausias Okinavos salos gyventojų patiekalas, turintis nemažai angliavandenių, yra ryžiai, kurių vietiniai gyventojai per dieną suvalgo apie tris porcijas (1 porcija yra 30 gramų grūdų produkto) (8). Ryžiai paprastai valgomi negardinti, todèl kiti patiekalai yra ryškesnio skonio, kas japoniškai virtuvei padeda sukurti jų taip vertinamą harmoniją (6). Vieni iš tradicinių rankomis susuktų suši (jap. temakizushi) - tai ryžiai su omleto, krabų mėsos, agurko ịdaru. İsukama ị jūros dumblių lakštą, įdedama marinuoto imbiero, vasabi krienų, šiek tiek ryžių acto, sojų padažo (6). Suši dažnai gaminamas bei vartojamas ir lietuviškose aplinkose, bet svarbu įvertinti jų sudètį - juose neturètų būti nei kreminio sūrio, nei majonezo, be to, jie neturi būti apkepti tešloje. Kitas mėgstamas vietiniu gyventojų ryžių patiekalas yra onigiriai (jap. onigiri) - virtų ryžių kukuliai, įdaryti žuvimi, marinuotomis daržovėmis arba mèsa. Jie atsirado gana seniai, kai dar nebuvo šaldymo technologijų, kad ryžiai ilgiau išsilaikytų švieži, japonai juos įdarydavo sūdytais arba raugintais produktais (6). Rauginti ir marinuoti produktai (jap. tsukemono) - tai būdas praturtinti mitybą ryškesniu sko-

1 lentelè. VGT ir mirštamumas Okinavoje bei kai kuriuose kituose pasaulio regionuose

Šaltinis: Pasaulinès sveikatos organizacija (PSO), 2015

\begin{tabular}{|l|c|c|c|c|}
\hline Šalis (regionas) & $\begin{array}{c}\text { VGT } \\
\text { (metai) }\end{array}$ & $\begin{array}{c}\text { Širdies } \\
\text { ligos }\end{array}$ & Věžys & Insultas \\
\hline Okinava & 81,2 & 18 & 97 & 35 \\
\hline $\begin{array}{l}\text { Likusi Japonijos } \\
\text { dalis }\end{array}$ & 79,9 & 22 & 106 & 45 \\
\hline Honkongas & 79,1 & 40 & 126 & 40 \\
\hline Švedija & 79 & 102 & 108 & 38 \\
\hline Italija & 78,3 & 55 & 135 & 49 \\
\hline Graikija & 78,1 & 55 & 109 & 70 \\
\hline JAV & 76,8 & 100 & 132 & 28 \\
\hline
\end{tabular}


niu, išsaugant gerąsias maisto savybes (naudojama druska, sojų padažas, ryžiu actas ar cukrus). Vienas populiariausių iš tsukemono yra sūdyti baltagūžiai kopūstai (jap. kyabeji no shiozuke), saldžiarūgštès daržovès (jap. fukujinzuke), ridikai (jap. takuan), o paprasčiausiai paruošiami - agurkai, apdoroti imbieru ir druska. Japonai dažnai pamarinuoja ir česnakus, imbierus, kiaušinius, miso pastoje - lašišą (jap. miso samon), o marinuotas šviežias tunas su ryžiais (jap. maguro zuke don) gali būti vartojamas jau tą pačią dieną (6).

Kaip ir grūdiniai (visadaliai) produktai bei ryžiai, taip ir daržovès Okinavos salos gyventojų valgiaraštyje užima tas pačias pozicijas, ir tiek grūdai, tiek daržovès yra valgomi 7-13 porcijų per dieną (8). Tik ne visada okinavų valgomi rudieji ryžiai, turintys daugiau maistinių medžiagų ir skaidulų, neretai - baltieji ryžiai. Okinavai nemažai vartoja omega-3 riebiujų rūgščių, kurios gaunamos iš daugelio žuvų, pupelių, linų sẻmenų aliejaus, moliūgo sẻklų, sojų produktų, graikinių riešutų ir kt. maisto (8). Beveik kasdien troškiniams, salotoms, užkandžiams gaminti yra vartojami dumbliai (6). Japonai gamina naikinančią bakterijas, sušildančią ir skatinančią virškinimą sojų pupelių pastą (jap. miso), kurią naudoja sriuboms (tradicinè japonų miso sriuba), troškiniams bei kaip marinatą (6). Saldumynų šios Ramiojo vandenyno salos gyventojai vartoja nedaug. Vietoj rafinuoto baltojo cukraus Okinavos salos gyventojai retkarčiais pasibarsto nerafinuoto cukranendrių cukraus, vartoja saldžiąsias pupeles, vaisius bei uogas.

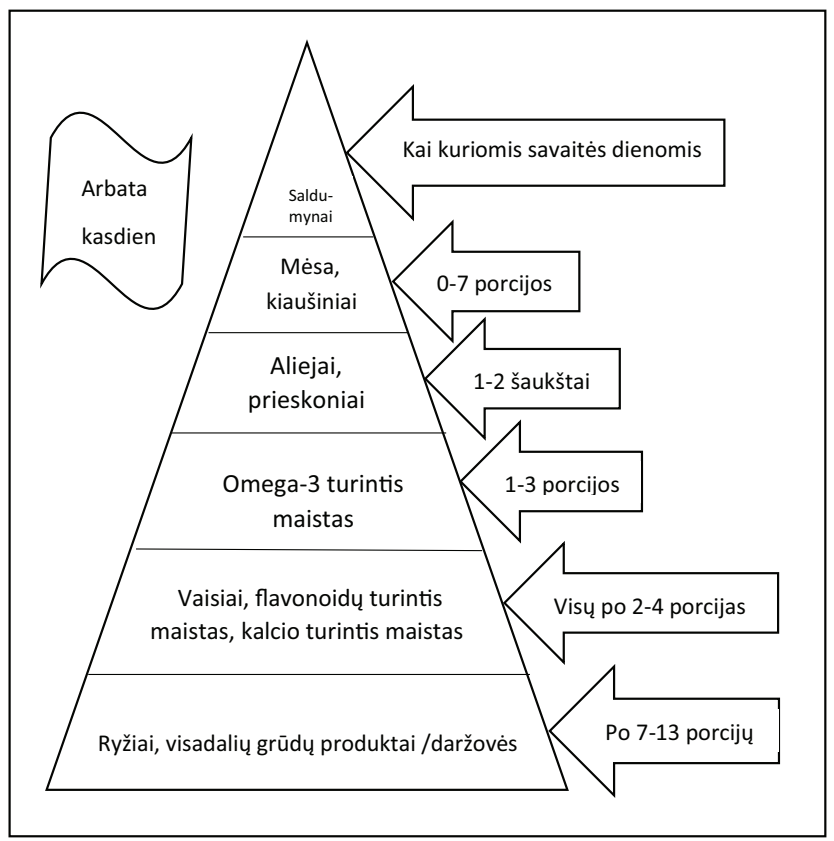

1 pav. Okinavos mitybos piramide remiantis Willcox BJ, Willcox DC, Suzuki M (2013)
Okinavos salos gyventojų mitybos piramide, sudaryta pagal jų realią mitybą, nuo tradicinès skiriasi tuo, kad yra omega-3 riebiųu rūgščių, didesnè svarba daržovėms, mažesnis mésos populiarumas bei ịvairesnis mitybos valgiaraštis (8) (1 pav.).

Vienas iš populiariausių japoniškų šeimyniškų patiekalų - ryžiai su vištiena ir kiaušiniais (jap. oyakodon), kepta skumbrè (jap. saba no kabayaki), kurioje daug vitamino A, D ir omega-3 riebiujų rūgščių (6). Ploni, rusvi grikių makaronai (jap. soba) yra populiarūs visoje Japonijoje ir valgomi su sultiniu ir ịvairiais priedais. Populiarus ir omletas, vištienos vėrinèliai. Šabu šabu (jap. shabu shabu) skirta valgyti visai šeimai, susèdusiai aplink šildomą japonišką stalą, ant kurio troškinamas sultinys su daržovèmis, žuvimi ar mėsa. Tai ne tik patiekalas, skirtas dalintis, bet ir suburiantis bendravimui ritualas.

Arbata ir jos ruošimo bei gèrimo ritualas yra neatsiejama Rytų šalių kultūros bei japonistikos dalis. Žalioji arbata turètų būti geriama be cukraus. Ji gausiai aprūpina organizmą flavonoidais. Yra ir daugiau okinaviečių vartojamų, flavonoidų gausa pasižyminčių produktų: sojų produktai, pupelès, lęšiai, obuolių sultys, avokadai, vyšnios, spanguolès, slyvos, linų sėmenys bei žalioji, jazminų arbatos. (8). Kavos, tiek Okinavos salos gyventojai, tiek likusios šalies dalies gyventojai, vartoja mažai.

Sékmingas Okinavos salos gyventojų mitybos atvejis, plètojamas mitybos raciono pasirinkimo, maisto apdorojimo, kai kurių produktų apribojimo tradicijose koreliuoja su gyventojų sveikata bei ilgaamžiškumu.

\section{Išvados}

1. Atvejo tyrimo būdas iggalina ieškoti plataus tyrinèjamos temos konteksto. Analizuojant Japonijos pietuose esančios Okinavos salos gyventojų mitybą, išskirtas ir tyrinètas istorinis, socialinis visos šalies bei Okinavos prefektūros kontekstas ir prevencinis požiūris ị sveikatą, išryškinant netinkamos mitybos pavojus. Tyrimo kontekstas plètojamas ir analizuojant sveikatai svarbią japoniškosios kultūros bei mitybos filosofiją.

2. Japonijos Okinavos salos gyventojų atvejo fenomenalumas ilgaamžiškumo kontekste slypi vietinių gyventojų mitybos tradicijose, kurios analizė išryškino šiuos Okinavos salos gyventojų mitybos raštingumo postulatus: neriebus maistas, augalinès kilmès produktų (ypač daržovių, jūros dumblių) vartojimas, visadalių grūdų, flavonoidų, omega-3 riebiujų rūgščių, kurių nemažai yra žuvyje, sojoje vartojimas, uogų, vaisių (ypač karčiojo žaliojo meliono) vartojimas bei gausus ciberžolès, žaliosios bei jazminų arbatos gèrimas. Okinavos salos gyventojai yra apriboję mėsos, saldumynų, kavos vartojimą. 
3. Ramus Okinavos salos gyventojų charakteris, pasitenkinimas gyvenimu, nuolatinè veikla, fizinis judejjimas, darnus santykis su kitais bei maisto ruošimo ir valgymo filosofija - tai papildantys mitybos veiksnị ištekliai, taip pat turintys reikšmès gerai šios salos gyventojų sveikatai ir ilgaamžiškumui.

\section{Literatūra}

1. Barzda A., Bartkevičiūtė R., Baltušytė I., Stukas R., Bartkevičiūtè S. Suaugusių ir pagyvenusių Lietuvos gyventojų faktinès mitybos ir mitybos ịpročiu tyrimas. Visuomenès sveikata, 2016; 1(72):85-93.

2. Brėdikis J. Kitokiu žvilgsniu. Vilnius. Santara, 2016.

3. Castells M. Tūkstantmečio pabaiga. Informacijos amžius. Ekonomika, visuomenè ir kultūra. III tomas. Kaunas: Poligrafija ir informatika, 2007.

4. Dobrovolskij V., Stukas R. Studentų mitybos ypatumai. Visuomenès sveikata, 2012; priedas Nr.1:14-18.

5. Jucevičius G. Nacionalinès vadybos sistemos: kultūra, institucijos, inovacijos: monografija. Kaunas. Technologija, 2014.

6. Norvaišaitè-Aleliūnienė I. Rytų Azijos virtuvė. Vilnius. UAB Media incognito, 2017.

7. Pruskus V., Kocai E. Sociologinių tyrimų organizavimas ir atlikimo metodika. Vilnius. Lietuvos edukologijos universiteto leidykla, 2014.

8. Willcox BJ, Willcox DC, Suzuki M. Rytų sveikatos dėsniai. Kaunas. Luceo, 2013.

\section{ANALYSIS OF THE OKINAWAN NUTRITION PHENOMENON: CASE STUDY I. Spiriajevienė}

Key words: Okinawa, Japan, nutrition, case study. Summary

The case study was conducted aiming to analyze the subject, using the literature analysis method, which was best suited to study the nutrition of the population of the prefecture of Okinawa in the Far East of the East Asia in the South of Japan. The case study made it possible to present a broad context of the topic under study, which was revealed in the article by the historical and social as- pects of the Okinawa, which is located in the Riukiu archipelago (Okinawa is one of the numerous islands), in the context of the philosophy of Japanese culture and nutrition as well. The context of research was elaborated by analyzing the preventive approach to health, the risk of malnutrition and other relevant circumstances relevant to this case study.

The inhabitants of the Okinawa Island, like the rest of the country, survived the Second World War, and later they raised and impressed the world with incredible economic progress and shifted to global technological leadership. The Okinawan people impressed the world with a youth elixir relevant to longevity, which is related to the phenomena of the Okinawan nutrition. In Okinawa, the average life expectancy of women is 86 years, and for men 78 years. On average, from 100000 of local inhabitants, a number of inhabitants over 100 years old is 34 , in comparison to the number of 7-8 inhabitants in the US respectively. It has been determined that the biggest concentration of 100 years old inhabitants located in the Okinawa. This fact has been entitled as gerontological phenomenon. It is important to note, that the health of Okinawan people remains strong for quite a long time, and the incidences of cardiovascular, oncological and other diseases are lower than in other countries of the world.

The phenomenon of the Japanese Okinawa population in the context of longevity related to the native traditions of the indigenous population. The analysis highlighted the following nutritional aspects in the Okinawa Island: low-fat meals, consumption of vegetable products (especially vegetables and seaweed), whole grains, flavonoids, omega-3 fatty acids consuming a lot of fish and other seafood, eating of berries, fruits (especially hot green melons) and drinking a lot of turmeric, green and jasmine tea. Most of the Okinawa people do not eat meet and sweets. This foodstuff was removed from nutrition. The fact, that the calm character of Okinawa's people and the feeling of life satisfaction, as well as physical movement and harmonious relationship with others, and the philosophy of cooking and eating, these are the resources that impact on the nutrition as well as on the health of Okinawa population. The cause of this impact is known as the Okinawan longevity.

Correspondence to: spiriajeviene@gmail.com

Gauta 2017-09-27 